\title{
Jurist-Diction
}

Volume 4 No. 5, September 202

\section{Keberlakuan Pengaturan Landas Kontinen Dalam Undang- Undang Nomor 1 Tahun 1973 Tentang Landas Kontinen Indonesia dan United Nations Convention on the Law Of the Sea 1982 (UNCLOS 1982)}

\author{
Achmad Indra Irfansyah \\ achmadindrairfansyah@gmail.com \\ Universitas Airlangga
}

\begin{abstract}
How to cite:
Achmad Indra Irfansyah, 'Keberlakuan Pengaturan Landas Kontinen Dalam Undang-Undang Nomor 1 Tahun 1973 Tentang Landas Kontinen Indonesia dan United Nations Convention on the Law Of the Sea 1982 (UNCLOS 1982)' (2021) Vol. 4

No. 5 Jurist-Diction.

Histori artikel:

Submit 11 Juli 2021;

Diterima 15 Agustus 2021;

Diterbitkan 1 September 2021

DOI:

10.20473/jd.v4i5.29816

p-ISSN: $2721-8392$

e-ISSN: 2655-8297
\end{abstract}

\begin{abstract}
Indonesia has taken steps to adjust its laws and regulations regarding maritime law with UNCLOS 1982, with the establishment of Law Number 6 of 1996 On Indonesian Waters however, this step not yet followed by adjustments to the laws regarding continental shelf, namely Law Number. 1 of 1973 On Indonesian Continental Shelf. The purpose of this research is to analize the differences in the substance of the arrangements for continental shelf in UNCLOS 1982 and Law Number 1 of 1973 On Indonesia Continental Shelf to find out the effectiveness of Indonesia's international treaties with other countries regarding the continental shelf using the Statute Approach and Conceptual Approach. Indonesia must make adjustments to national legislation regarding continental shelf with UNCLOS 1982 because of Indonesian legislation regarding continental shelf still refers to United Nations Convention on the Continental Shelf 1958.

Keywords: Continental Shelf; Natural Resources;UNCLOS 1982.
\end{abstract}

\begin{abstract}
Abstrak
Indonesia telah mengambil langkah untuk menyesuaikan peraturan perundang-undangannya mengenai hukum laut dengan UNCLOS 1982, yaitu disahkannya Undang-Undang Nomor 6 Tahun 1996 Tentang Perairan Indonesia namun langkah tersebut belum diikuti dengan penyesuaian peraturan perundang-undangan mengenai landas kontinen yaitu Undang-Undang Nomor 1 Tahun 1973 Tentang Landas Kontinen Indonesia. Tujuan dari penelitian ini adalah untuk mengetahui perbedaan substansi pengaturan tentang landas kontinen di dalam UNCLOS 1982 dan Undang-Undang Nomor 1 Tahun 1973 Tentang Landas Kontinen Indonesia sebagai sumber hukum mengenai landas kontinen di Indonesia, serta untuk mengetahui keberlakuan perjanjian-perjanjian internasional Indonesia dengan negara lain mengenai landas kontinen dengan menggunakan pendekatan undangundang (Statute Approach) dan pendekatan konseptual (Conceptual Approach). Indonesia harus melakukan penyesuaian peraturan perundang-undangan nasional tentang landas kontinen dengan UNCLOS 1982 karena peraturan perundang-undangan Indonesia tentang landas kontinen masih mengacu kepada United Nations on the Continental Shelf 1958.

Kata Kunci: Landas Kontinen; Sumberdaya Alam; UNCLOS 1982.

Copyright (C) 2021 Achmad Indra Irfansyah
\end{abstract}




\section{Pendahuluan}

Definisi laut adalah keseluruhan rangkaian air asin yang menggenangi permukaan bumi. Definisi ini hanya bersifat fisik semata. Laut menurut definisi hukum adalah keseluruhan air laut yang berhubungan secara bebas di seluruh permukaan bumi. ${ }^{1}$ Pentingnya laut dalam hubungan antar bangsa menyebabkan pentingnya pula arti hukum laut internasional. Tujuan hukum ini adalah untuk mengatur kegunaan rangkap dari laut, yaitu sebagai jalan raya dan sebagai sumber kekayaan dan sumber tenaga seperti bahan-bahan tambang dan galian terutama mineral, minyak, dan gas bumi.

Konferensi PBB pertama tentang hukum laut dilaksanakan di Jenewa pada tanggal 24 Februari sampai dengan 29 April 1958. Sebanyak 86 negara mengirimkan perwakilan negaranya untuk menghadiri konferensi tersebut, yang kemudian melahirkan 4 Konvensi tentang hukum laut, yakni Convention on the Territorial Sea and the Contiguous Zone (entry into force: 10 September 1964), Convention on the High Seas (entry into force: 30 September 1962), Convention on Fishing and Conservation of the Living Resources of the High Seas (entry into force: 20 Maret 1966), dan Convention on the Continental Shelf (entry into force 10 Juni 1964). Tidak berselang lama, Majelis Umum PBB meminta Sekretaris Jenderal PBB untuk mengadakan Konferensi PBB Kedua tentang Hukum Laut untuk mempertimbangkan topik-topik luasnya batas laut teritorial dan perikanan, yang belum disepakati dalam konvensi sebelumnya yang konferensinya diadakan mulai tanggal 17 Maret sampai dengan 26 April 1960 namun tidak menghasilkan perjanjian baru. Pada tahun 1973 diadakan Konferensi PBB Ketiga tentang hukum laut dan melahirkan konvensi hukum laut yang masih menjadi sumber hukum laut yang masih relevan hingga saat ini yaitu United Nations Convention on the Law Of the Sea 1982 (selanjutnya disebut UNCLOS 1982).

UNCLOS 1982 mengatur terkait dengan batas-batas maritim, pengaturan tersebut mengatur pembagian laut atas tiga bagian, yang pertama ialah bagian laut

\footnotetext{
1 Boer Mauna, Hukum Internasional Pengertian Peranan Dan Fungsi Dalam Era Dinamika Global (Penerbit Alumni 2001).[269].
} 
yang bukan menjadi bagian dari kedaulatan (sovereignty) maupun hak berdaulat (sovereign right) suatu negara pantai yaitu terdiri dari laut lepas (high seas) dan Area/kawasan (the deep sea bed), dan yang kedua ialah bagian laut yang menjadi kedaulatan negara pantai yaitu laut teritorial (teritorial sea), perairan pedalaman (internal seas), perairan kepulauan (archipelagic seas), dan daerah yang berlaku rezim hak berdaulat bagi negara pantai, yaitu zona tambahan (contigous zone) dan zona ekonomi eksklusif (exclusive economic zone), juga mengatur tentang dasar laut dan tanah dibawahnya yang disebut dengan landas kontinen (continental shelf), zonasi laut yang terurai diatas sesuai dengan ilustrasi berikut: ${ }^{2}$

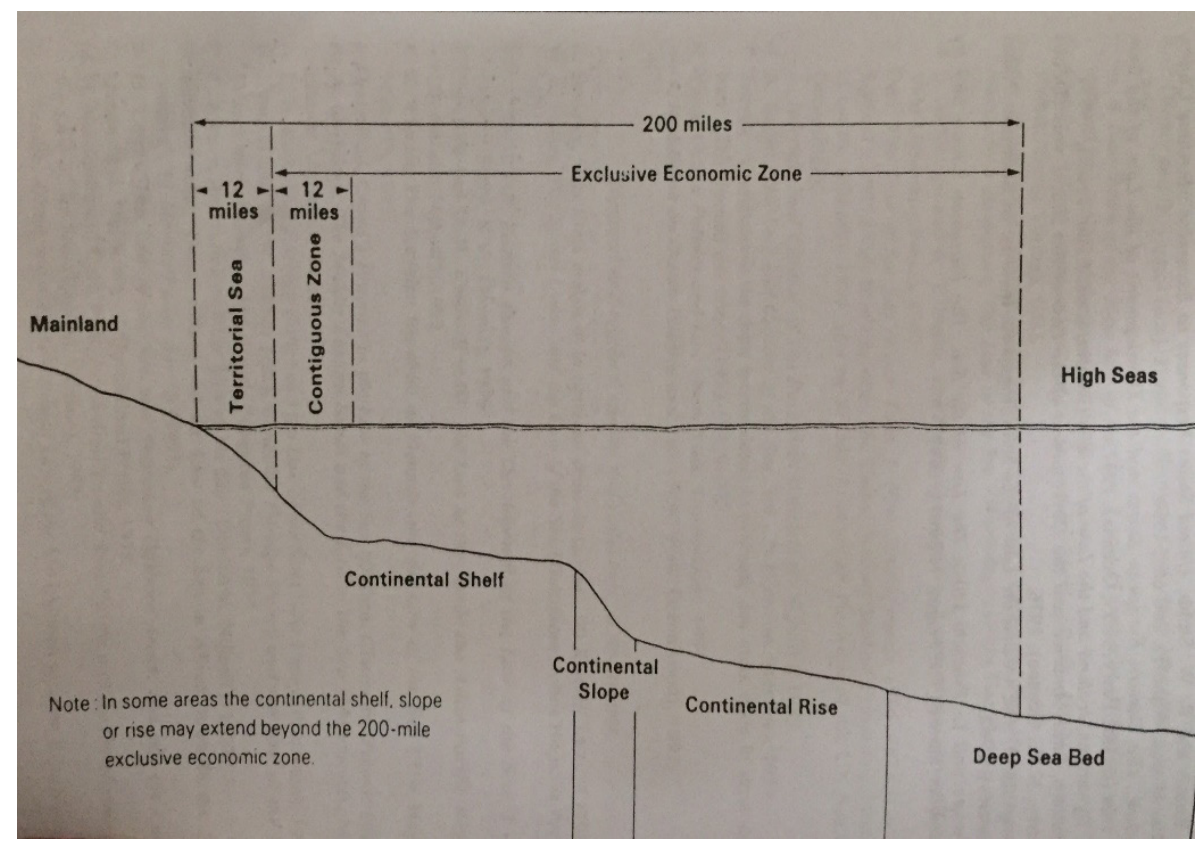

Gambar 1. Zonasi laut menurut UNCLOS 1982

Pemerintah Indonesia melalui Deklarasi Djuanda, mengumumkan secara unilateral/sepihak bahwa lebar laut wilayah Indonesia adalah $12 \mathrm{~nm}$. Lalu Indonesia meratifikasi 3 konvensi hukum laut internasional hasil dari Konferensi PBB Pertama mengenai Hukum Laut melalui Undang-Undang Nomor 19 Tahun 1961 Tentang Persetujuan Atas Tiga Konvensi Jenewa Tahun 1958 Mengenai Hukum Laut, yakni mengenai Pengambilan Ikan Serta Hasil Laur dan Pembinaan Sumber Hayati Laut

${ }^{2}$ R. R. Churcill dan A.V. Lowe, The Law of the Sea Third Edition, Jurist Publishing (Manchester University Press 1999).[30]. 
Bebas, Dataran Kontinental, dan Laut Lepas. ${ }^{3}$ Ratifikasi tersebut disertai dengan suatu reservasi bahwa yang dimaksudkan dengan laut bebas dalam Konvensi tersebut adalah bagian laut yang terletak di luar Perairan Nusantara Indonesia. Barulah dengan Peraturan Pemerintah Pengganti Undang-Undang Nomor 4 Tahun 1960 Tentang Perairan Indonesia (selanjutnya disebut UU No. 4 Prp Tahun 1960) ditetapkan ketentuan tentang laut wilayah Indonesia selebar $12 \mathrm{~nm}$ laut dari garis pangkal lurus.

Puncak diplomasi yang dilakukan Indonesia yaitu memperjuangkan konsepsi negara kepulauan ialah pada saat konsep tersebut diterima dalam UNCLOS 1982, melalui Undang-Undang Nomor 17 Tahun 1985 Tentang Pengesahan United Nations Convention on the Law of The Sea 1982 (selanjutnya disebut UU No. 17 Tahun 1985), Pemerintah Indonesia meratifikasi/mengesahkan UNCLOS 1982 tersebut dan resmi menjadi negara pihak. Sebagai tindak lanjut dari pengesahan UNCLOS 1982 melalui UU No. 17 Tahun 1985, Pemerintah Indonesia telah menerbitkan Undang-Undang Nomor 6 Tahun 1996 Tentang Perairan Indonesia (selanjutnya disebut UU No.6 tahun 1996) dan Peraturan Pemerintah Nomor 38 Tahun 2002 Tentang Daftar Koordinat Geografis Titik-Titik Garis Pangkal Kepulauan Indonesia (selanjutnya disebut PP No.38 Tahun 2002). Dua Landasan hukum tersebut, khususnya PP No.38 Tahun 2002, telah menjadi pagar batas wilayah perairan Indonesia sejak dicabutnya UU No. 4 Prp Tahun 1960 melalui UU No.6 Tahun 1996.

Bagi Indonesia, diratifikasinya UNCLOS 1982 melalui UU No. 17 Tahun 1985 merupakan tonggak sejarah yang sangat penting karena Landas Kontinen diatur dalam Bab tersendiri, yaitu Bab VI, mulai dari Pasal 76 sampai dengan Pasal 85. Undang-Undang Nomor 1 Tahun 1973 Tentang Landas Kontinen Indonesia (UU No. 1 Tahun 1973) merupakan hasil tindak lanjut Pemerintah Indonesia terhadap Convention on the Continental Shelf 1958, sebelum terbitnya UNCLOS

${ }^{3} \mathrm{NN}$, 'Undang-Undang Nomor 19 Tahun 1961'<https://m.hukumonline.com/pusatdata/ detail/25523/nprt/939/undangundang-nomor-19-tahun-1961>, accessed 27 Desember 2019. 
1982. ${ }^{4}$ Pengertian landas kontinen dalam arti yuridis ialah dasar laut dan tanah di bawahnya yang terletak di luar area laut teritorial dari sebuah pulau. Kawasan dasar laut dan tanah dibawahnya sebelumnya merupakan Area berlaku rezim common heritage of mankind (warisan bersama umat manusia), setelah menjadi landas kontinen dari suatu negara pantai, maka Pasal 77 UNCLOS 1982 mengenai hakhak negara pantai atas landas kontinen berlaku kepada negara pantai tersebut. ${ }^{5}$

Pengertian Landasan kontinen menurut UNCLOS 1982 yang telah diratifikasi dengan UU No. 17 Tahun 1985 merupakan wilayah dasar laut dan juga tanah di bawahnya yang bersambungan dengan pantai tetapi di luar laut teritorial hingga jarak $200 \mathrm{~nm}$ atau lebih hingga $350 \mathrm{~nm}$, sepanjang dalamnya air laut di atasnya masih memungkinkan untuk dapat mengeksplorasi dan juga mengeksploitasi sumber-sumber daya alam yang dimilikinya, dengan kata lain tidak memiliki kedalaman melebihi $100 \mathrm{~nm}$ dari garis kedalaman (isobath) 2500 meter. ${ }^{6}$ Pengertian landas kontinen menurut UU No. 1 Tahun 1973 merupakan dasar laut dan tanah dibawahnya diluar perairan wilayah Republik Indonesia sebagaimana diatur dalam Undang-undang Nomor 4 Prp. Tahun 1960 sampai kedalaman 200 meter atau lebih, dimana masih mungkin diselenggarakan eksplorasi dan eksploitasi kekayaan alam. ${ }^{7}$

Pengaturan mengenai landas kontinen di Indonesia dalam UU No. 1 Tahun 1973 masih mengacu pada ketentuan Convention on the Continental Shelf 1958. Sementara Indonesia telah meratifikasi UNCLOS 1982 melalui UU No. 17 Tahun 1985, dimana kriteria dalam konvensi ini dinilai lebih menguntungkan bagi negara pantai. Ditambah UU No. 1 Tahun 1973 yang masih mengacu pada UU No. 4 Prp Tahun 1960 untuk urusan eksploitasi dan eksplorasi laut, ${ }^{8}$ dimana keberlakuan UU No. 4 Prp tahun 1960 telah dicabut dan digantikan oleh UU No. 6 Tahun 1996. Adanya perkembangan tersebut tidak diikuti dengan pembaharuan UU No. 1 Tahun

\footnotetext{
${ }^{4}$ Suparman A.Diraputra, 'Naskah Akademik RUU Tentang Landas Kontinen' <www.bphn. go.id>.[1-2], accessed 16 Februari 2016.

${ }^{5}$ United Nations Convention on the Law of the Sea 1982.

${ }^{6}$ ibid.

${ }^{7}$ Undang-Undang Nomor 1 Tahun 1973 Tentang Landas Kontinen Indonesia.

${ }^{8}$ ibid.
} 
1728 Achmad Indra: Keberlakuan Pengaturan Landas...

1973 yang seharusnya mengacu pada kriteria yang lebih relevan berdasarkan UNCLOS 1982 yang telah diratifikasi melalui UU No. 17 Tahun 1985.

\section{Pengaturan Tentang Landas Kontinen Dalam Undang-Undang Nomor 1}

Tahun 1973 Tentang Landas Kontinen Indonesia dan UNCLOS 1982

\begin{tabular}{|c|c|c|c|}
\hline Pengaturan & UU No. 1 Tahun 1973 & UNCLOS 1982 & Keterangan \\
\hline $\begin{array}{l}\text { Definisi dan } \\
\text { Pengukuran } \\
\text { Landas Kontinen }\end{array}$ & $\begin{array}{l}\text { Dasar laut dan tanah } \\
\text { dibawahnya diluar } \\
\text { perairan wilayah Re- } \\
\text { publik Indonesia den- } \\
\text { gan kedalaman } 200 \mathrm{~m} \\
\text { atau lebih, dimana ma- } \\
\text { sih mungkin diseleng- } \\
\text { garakan eksplorasi dan } \\
\text { eksploitasi kekayaan } \\
\text { alam. }{ }^{9}\end{array}$ & $\begin{array}{l}\text { - Dasar laut dan tanah } \\
\text { dibawahnya yang } \\
\text { terletak diluar rezim } \\
\text { laut teritorial sepanjang } \\
\text { kelanjutan alamiah } \\
\text { wilayah daratannya } \\
\text { hingga hingga pinggiran } \\
\text { luar tepi kontinen, } \\
\text { atau hingga jarak 200 } \\
\text { nm dari garis pangkal } \\
\text { darimana laut teritorial } \\
\text { diukur (Basepoint). } \\
\text { - Terdapat empat } \\
\text { alternatif cara untuk } \\
\text { mengukur batas terluar } \\
\text { landas kontinen: } \\
\text { a.Sampai batas terluar } \\
\text { tepian kontinen. } \\
\text { b.Sampai jarak } 200 \text { nm } \\
\text { dari garis pangkal laut. } \\
\text { c.Apabila tepian } \\
\text { kontinen melebihi } \\
\text { 200 nm ke arah laut } \\
\text { maka batas terluar } \\
\text { landas kontinen tidak } \\
\text { boleh melebihi } 350 \\
\text { nm. } \\
\text { d.Boleh melebihi } 100 \\
\text { nm dari kedalaman } \\
\text { (isobath) 2500 meter. } \\
\text { Cara pengukuran batas } \\
\text { terluar landas kontinen } \\
\text { tersebut tergantung } \\
\text { pada konfigurasi tepian } \\
\text { kontinen dari suatu } \\
\text { negara pantai. Oleh } \\
\text { karena itu, suatu negara } \\
\text { pantai dapat menetapkan } \\
\text { batas terluar landas } \\
\text { kontinen yang berbeda- } \\
\text { beda di sekeliling- } \\
\text { wilayahnya. }\end{array}$ & $\begin{array}{l}\text { - Terdapat perbedaan } \\
\text { yang mencolok } \\
\text { antara definisi landas } \\
\text { kontinen dalam UU } \\
\text { No. 1 Tahun 1973 } \\
\text { dengan UNCLOS } \\
\text { 1982. Dalam UU } \\
\text { No. 1 Tahun 1973 } \\
\text { batas terluar landas } \\
\text { kontinen ditentukan } \\
\text { pada kedalaman } \\
\text { 200 meter dengan } \\
\text { kriteria eksploitasi, } \\
\text { sedangkan UNCLOS } \\
\text { 1982 memberikan } \\
\text { empat alternatif cara } \\
\text { mengukurbatas terluar } \\
\text { landas kontinen. } \\
\text { - Jika dibandingkan } \\
\text { dengan ketentuan UU } \\
\text { No. 1 Tahun 1973, } \\
\text { perumusan yang } \\
\text { terdapat dalam Pasal } \\
\text { 76 UNCLOS 1982 } \\
\text { memberikan batasan } \\
\text { yang lebih jelas } \\
\text { tentang batas terluar } \\
\text { landas kontinen. } \\
\text { - Dalam UU No. } \\
1 \text { Tahun 1973 } \\
\text { tidak terdapat } \\
\text { ketentuan tentang } \\
\text { garis Extended } \\
\text { Continental Shelf. } \\
\text { Setiap negara pantai } \\
\text { boleh melakukan } \\
\text { klaim batas terluar } \\
\text { landas kontinen } \\
\text { diluar 200 nm hingga } \\
\text { 350 nm atau 2500m } \\
\text { (isobath)=100 nm }\end{array}$ \\
\hline
\end{tabular}

\footnotetext{
9 ibid.

${ }^{10}$ United Nations Convention on the Law Of the Sea 1982, Op.Cit.
} 
- Landas Kontinen suatu negara pantai tidak boleh melebihi batasbatas sebagaimana ditentukan dalam Pasal 76 ayat (4) hingga (6). Tepian kontinen meliputi kelanjutan bagian daratan negara pantai yang berada di bawah permukaan air, dan terdiri dari dasar laut dan tanah dibawahnya dari daratan kontinen lereng (Slope) dan tanjakan (Rise). Tepian kontinen tidak mencakup dasar samudera dalam dengan bukit-bukit samudera atau tanah dibawahnya.

- Konvensi ini menentukan bahwa negara pantai akan menetapkan pinggiran luat tepian kontinen dalam hal tepian kontinen tersebut tidak lebih lebar dari $200 \mathrm{~nm}$ dari basepoint dimana laut teritorial diukur, atau dengan:

a. Suatu garis yang ditarik sesuai dengan ayat (7) dengan menunjuk pada titiktitik tetap terluar dimana ketebalan batu endapan adalah paling sedikit $1 \%$ dari jarak terdekat antara titik-titik tersebut dan kaki lereng kontinen; atau

b. Suatu garis yang ditarik sesuai dengan ayat (7) dengan menunjuk pada titiktitik tetap yang terlet- asalkan mampu

$\mathrm{m}$ e $\mathrm{l}$ a $\mathrm{k} \mathrm{u} \mathrm{k}$ a $\mathrm{n}$ eksplorasi dan eksploitasi di luar batas tersebut. 


\begin{tabular}{|c|c|c|c|}
\hline & & $\begin{array}{l}\text { etak tidak lebih dari } \\
60 \text { nm dari kaki lereng } \\
\text { kontinen. } \\
\text { - Dalam hal tidak } \\
\text { terdapatnya bukti yang } \\
\text { bertentangan, kaki } \\
\text { lereng kontinen harus } \\
\text { ditetapkan sebagai titik } \\
\text { perubahan maksimum } \\
\text { dalam tanjakan pada } \\
\text { kakinya. Titik-titik } \\
\text { tetap yang merupakan } \\
\text { garis batas luar landas } \\
\text { kontinen pada dasar } \\
\text { laut, yang ditarik sesuai } \\
\text { ayat (4), atau tidak } \\
\text { akan boleh melebihi } \\
\text { 350 nm dari basepoint } \\
\text { atau tidak boleh } \\
\text { melebihi } 100 \text { nm dari } \\
\text { garis batas kedalaman } \\
\text { (Isobath) 2500 meter, } \\
\text { yaitu suatu garis yang } \\
\text { m e n h u b u } \mathrm{n} \text { k a n } \\
\text { kedalaman } 2500 \text { meter. } \\
\text { - Walaupun ada ketentuan } \\
\text { ayat (5) pada bukit- } \\
\text { bukit dasar laut, batas } \\
\text { luar landas kontinen } \\
\text { tidak boleh melebihi } \\
\text { 350 nm dari Basepoint. } \\
\text { Ayat ini tidak berlaku } \\
\text { bagi elevasi dasar } \\
\text { laut yang merupakan } \\
\text { bagian-bagian ilmiah } \\
\text { tepian kontinen, seperti } \\
\text { pelataran, tanjakan, } \\
\text { puncak, ketinggian } \\
\text { yang datar, dan puncak } \\
\text { gunung yang bulat. }\end{array}$ & \\
\hline $\begin{array}{l}\text { Status Hukum } \\
\text { Landas Kontinen }\end{array}$ & $\begin{array}{l}\text { Status Hukum dalam } \\
\text { undang-undang ini } \\
\text { mencakup status hak } \\
\text { ekslusif atas kekayaan } \\
\text { alam di Landas } \\
\text { Kontinen Indonesia } \\
\text { serta hak kepemilikan } \\
\text { negara. }{ }^{11}\end{array}$ & $\begin{array}{l}\text { Hak negara pantai } \\
\text { atas landas kontinen } \\
\text { tidak mempengaruhi } \\
\text { status hukum wilayah } \\
\text { laut setelah batas laut } \\
\text { teritorial, perairan atau } \\
\text { ruang udara di atasnya. } \\
\text { Negara pantai memiliki } \\
\text { hak berdaulat di atas land- }\end{array}$ & $\begin{array}{lr}\text { UU No. 1 } & \text { Tahun } 1973 \\
\text { hanya } & \text { mencakup } \\
\text { pengaturan } & \text { mengenai } \\
\text { statuss } & \text { hukum } \\
\text { kekayaan } & \text { landas } \\
\text { kontinennya r saja, } & \text { namun tidak ada } \\
\text { pengaturan } & \text { yang } \\
\text { mengenai representasi- }\end{array}$ \\
\hline
\end{tabular}

\footnotetext{
${ }^{11}$ Undang-Undang No. 1 Tahun 1973, Op.Cit.
} 


\begin{tabular}{|c|c|c|c|}
\hline & & $\begin{array}{l}\text {-s kontinen untuk secara } \\
\text { eksklusif } \\
\text { eksplorasi dan eksploitasi } \\
\text { di wilayah tersebut, tetapi } \\
\text { tidak boleh mengurangi } \\
\text { atau mengakibatkan } \\
\text { gangguan } \\
\text { terhadap apapun } \\
\text { dan hak negara lain } \\
\text { sebagaimana ditentukan } \\
\text { dalam } \\
\text { konvensi. }{ }^{12}\end{array}$ & $\begin{array}{l}\text { hak berdaulat diatas } \\
\text { wilayah landas } \\
\text { kontinen (perairan dan } \\
\text { ruang udara diatasnya). }\end{array}$ \\
\hline Instalasi & $\begin{array}{l}\text { - Untuk pemasangan } \\
\text { instalasi-instalasi } \\
\text { dan alat-alat } \\
\text { eksploitasi harus } \\
\text { m e n e t a p k a } \mathrm{n} \\
\text { "safety zone" di } \\
\text { sekelilingnya tidak } \\
\text { melebihi } 500 \text { m. }{ }^{13} \\
\text { - Pemerintah juga } \\
\text { dapat menetapkan } \\
\text { suatu daerah terbatas } \\
\text { selebar tidak lebih } \\
\text { dari } 1.250 \text { meter } \\
\text { terhitung dari titik- } \\
\text { titik terluar dari } \\
\text { daerah terlarang } \\
\text { itu, dimana kapal- } \\
\text { kapal pihak ketiga } \\
\text { dilarang membuang } \\
\text { atau membongkar } \\
\text { sauh sebagai } \\
\text { aturan lanjutan dari } \\
\text { Pemerintah Republik } \\
\text { Indonesia. }{ }^{14}\end{array}$ & $\begin{array}{l}\text { Negara pantai harus } \\
\text { menetapkan "safetyzone" } \\
\text { yang tidak melebihi } 500 \\
\text { m di sekeliling instalasi, } \\
\text { selain itu negara pantai } \\
\text { mempunyai yurisdiksi } \\
\text { ekslusif atas pulau-pulau } \\
\text { buatan, instalasi-instalasi } \\
\text { dan bangunan, dan } \\
\text { termasuk yang bertalian } \\
\text { dengan peraturan bea- } \\
\text { cukai, fiskal, keselamatan, } \\
\text { kesehatan, dan imigrasi. }{ }^{15}\end{array}$ & $\begin{array}{lr}\text { UNCLOS } & 1982 \\
\text { mencakup pengaturan } \\
\text { yang lebih luas } \\
\text { dibandingkan UU No. } \\
1 \text { Tahun 1973, selain } \\
\text { mengatur } \\
\text { yurisdiksi } \\
\text { instalasi, ekslusif } \\
\text { 1982 juga mengatur } \\
\text { mengenai yurisdiksi } \\
\text { yang bertalian } \\
\text { dengan bea-cukai, } \\
\text { fiskal, kesalamatan, } \\
\text { kesehatan, } \\
\text { imigrasi. }\end{array}$ \\
\hline $\begin{array}{l}\text { Kewajiban Yang } \\
\text { Berhubungan } \\
\text { Dengan Kegiatan } \\
\text { Eksplorasi Dan } \\
\text { Eksploitasi }\end{array}$ & & $\begin{array}{lr}\text { - Negara } & \text { pantai } \\
\text { diwajibkan } & \text { untuk } \\
\text { membayar } & \text { sumbangan } \\
\text { bertalian } & \text { dengan } \\
\text { kegiatan eksploitasi di } \\
\text { landas kontinennya di } \\
\text { luar 200 nm. }{ }^{16}\end{array}$ & $\begin{array}{l}\text { Tidak diatur lebih } \\
\text { lanjut dalam UU No. } 1 \\
\text { Tahun } 1973 .\end{array}$ \\
\hline
\end{tabular}

\footnotetext{
${ }^{12}$ United Nations Convention on the Law Of the Sea 1982, Op.Cit.

${ }^{13}$ Undang-Undang No. 1 Tahun 1973, Op.Cit.

${ }^{14}$ ibid.

${ }^{15}$ United Nations Convention on the Law of the Sea 1982, Op.Cit.

${ }^{16}$ ibid.
} 


\begin{tabular}{|c|c|c|c|}
\hline & & $\begin{array}{l}\text { - P e m b a y r a n y a } \\
\text { diberikan setelah } \\
\text { produksi } 5 \text { tahun } \\
\text { pertama pada tempat itu } \\
\text { sebesar } 1 \% \text { dari jumlah } \\
\text { produksi di tempat itu } \\
\text { kemudian akan naik } \\
1 \% \text { untuk tiap tahun } \\
\text { berikutnya hingga tahun } \\
\text { ke } 12 \text { akan tetap } 7 \% \text {. } \\
\text { - Sumbangan hanya untuk } \\
\text { kegiatan eksploitasi } \\
\text { sumber mineral dan } \\
\text { tidak dikenakan } \\
\text { pada kegiatan landas } \\
\text { kontinen } 200 \text { nm dari } \\
\text { garis pangkal yang } \\
\text { berhimpit dengan zona } \\
\text { ekonomi eksklusif. }\end{array}$ & \\
\hline $\begin{array}{l}\text { Penetapan Garis } \\
\text { Batas Landas } \\
\text { Kontinen Negara } \\
\text { Pantai Yang } \\
\text { Berhadapan }\end{array}$ & $\begin{array}{lr}\text { Dalam hal landas } \\
\text { kontinen } & \text { Indonesia } \\
\text { termasuk } & \text { deprasi- } \\
\text { depresi yang } & \text { terdapat } \\
\text { dalam } & \text { landas } \\
\text { kontinen } & \text { Indonesia } \\
\text { bebatasan } & \text { dengan } \\
\text { negara lain, penetapan } \\
\text { garis batas landas } \\
\text { kontinen } & \text { dengan } \\
\text { negara lain } & \text { dapat } \\
\text { dilakukan } & \text { dengan } \\
\text { cara mengadakan } \\
\text { perundingan } \\
\text { mencapai untuk } \\
\text { persetujuan. }\end{array}$ & 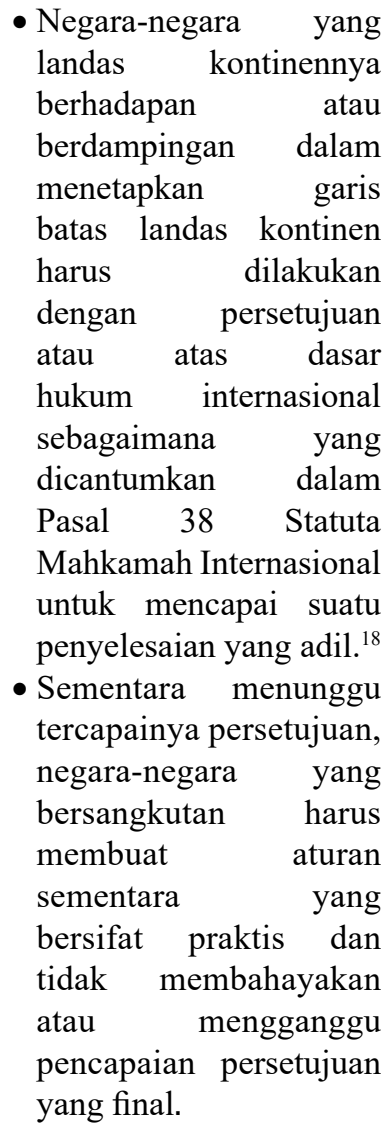 & $\begin{array}{l}\text { Baik UU No. } 1 \\
\text { Tahun } 1973 \text { dan } \\
\text { UNCLOS } \\
\text { memberi keleluasaan } \\
\text { tentang metode yang } \\
\text { digunakan melalui } \\
\text { persetujuan atas dasar } \\
\text { hukum internasional } \\
\text { serta lebih menekan } \\
\text { kepada tercapainya } \\
\text { kesepakatan antar } \\
\text { negara-negara yang } \\
\text { bersangkutan, namun } \\
\text { didalam UNCLOS } \\
\text { 1982 diatur lebih } \\
\text { terperinci beserta } \\
\text { akibat-akibatnya. }\end{array}$ \\
\hline
\end{tabular}

\footnotetext{
${ }^{17}$ Undang-Undang No. 1 Tahun 1973, Op.Cit.

${ }^{18}$ United Nations Convention on the Law Of the Sea 1982, Op.Cit.
} 


\begin{tabular}{|c|c|c|c|}
\hline \multirow[t]{2}{*}{ Ketentuan Pidana } & $\begin{array}{l}\text { Tindak pidana yang } \\
\text { dilakukan terhadap } \\
\text { landas kontinen } \\
\text { Indonesia kecuali tidak } \\
\text { diatur secara khusus } \\
\text { dalam undang-undang } \\
\text { lain, diancam dengan } \\
\text { hukuman penjara } \\
\text { selama-lamanya } 6 \\
\text { tahun dan/atau denda } \\
\text { setinggi-tingginya Rp. } \\
\text { 1.000.000,- jika tidak } \\
\text { mematuhi Pasal } 4 \text { UU } \\
\text { No. 1 Tahun } 1973 \text { dan } \\
\text { ketentuan-ketentuan }\end{array}$ & $\begin{array}{l}\text { Tidak diatur karena } \\
\text { ketentuan pidana termasuk } \\
\text { kapasitas kedaulatan dan } \\
\text { hak berdaulat suatu negara } \\
\text { melalui hukum nasional. }\end{array}$ & $\begin{array}{l}\text { UNCLOS } \\
\text { sebagai sumber hukum } \\
\text { laut internasional tidak } \\
\text { mengatur ketentuan } \\
\text { pidana yang menjadi } \\
\text { kapasitas suatu } \\
\text { kedaulatan negara dan } \\
\text { hak berdaulat suatu } \\
\text { negara. }\end{array}$ \\
\hline & $\begin{array}{lr}\text { dalam Peraturan } \\
\text { Pemerintah yang } \\
\text { ditetapkan berdasarkan } \\
\text { pasal } 5 \text { dan pasal 8 UU } \\
\text { No. 1 Tahun 1973. }\end{array}$ & & \\
\hline
\end{tabular}

Berdasarkan hasil analisa pengaturan tentang Landas Kontinen di dalam UU No. 1 Tahun 1973 dengan UNCLOS 1982, ${ }^{19}$ banyak ketentuan-ketentuan yang sudah di amandemen di dalam UNCLOS 1982, khususnya pengaturan tentang landas pembangunan instalasi, Extended Continental Shelf, serta kewajiban yang berhubungan dengan kegiatan eksplorasi dan eksploitasi, dari ketiga hal tersebut ada yang sudah diatur dan belum diatur dalam UU No. 1 Tahun 1973 namun substansi pengaturannya telah di amandemen di dalam UNCLOS 1982, serta pentingnya undang-undang nasional juga penting keberadaanya untuk mengatur tentang ketentuan-ketentuan pidana di landas kontinen. Hal ini mengisyaratkan bahwa UU No. 1 Tahun 1973 sudah tidak relevan dengan rezim hukum laut khususnya Landas Kontinen yang telah diatur dalam UNCLOS 1982.

\footnotetext{
${ }^{19}$ Ratih D. Starina dan T. Fayakun Alif, 'Analisa Revisi UU no 1 tahun 1973 tentang Landas Kontinen Indonesia yang mengacu pada UNCLOS 1958 dengan menggunakan UNCLOS 1982', Jurnal, (Pusat Pemetaan Dasar Kelautan dan Kedirgantaraan BAKOSURTAN AL 2011).[4].
} 


\section{Keberlakuan Perjanjian Landas Kontinen Sebelum dan Sesudah Berlakunya Undang-Undang Nomor 17 Tahun 1985 Tentang Pengesahan United Nations Convention on the Law Of the Sea 1982}

Daftar Perjanjian Internasional tentang Landas Kontinen antara Indonesia dengan Negara Lain yang dianalisa:

1. Perjanjian Antara Pemerintah Republik Indonesia dan Pemerintah Republik India Tentang Penetapan Garis Batas Landas Kontinen Antara Kedua Negara 1974;

2. Perjanjian Antara Pemerintah Republik Indonesia, Pemerintah Republik India dan Pemerintah Kerajaan Thailand Tentang Penetapan Titik Pertemuan Tiga Garis Batas dan Penetapan Garis Batas Ketiga Negara di Laut Andaman 1978;

3. Perjanjian Antara Pemerintah Republik Indonesia dan Pemerintah Republik Sosialis Vietnam Tentang Penetapan Batas Landas Kontinen 2003;

4. Memorandum of Understanding Antara Kementerian Energi dan Sumber Daya Mineral Republik Indonesia dan Kementerian Industri dan Perdagangan Republik Sosialis Vietnam Tentang Kerja Sama di Bidang Pemanfaatan Gas Pada Wilayah Lintas Batas Landas Kontinen.

Dalam perjanjian yang lahir sebelum terbitnya UU No. 1 Tahun 1985, maupun perjanjian yang lahir setelah terbitnya UU No. 1 Tahun 1985, terlihat ada kesamaan dalam bentuk dan pola substansinya. Mulai dari penetapan kawasan yang ditetapkan sebagai garis batas landas kontinen antara Indonesia dengan pihak negara peserta perjanjian lainnya yang disertai dengan titik-titik koordinatnya, dilanjutkan dengan pengaturan tentang sumber daya alam lintas batas, pengaturan ketatanegaraan tentang penyelesaian sengketa, dan pada akhirnya pengaturan yang berupa pengesahan menurut hukum nasional masing-masing pihak. Dalam MoU Antara Kementerian Energi dan Sumber Daya Mineral Republik Indonesia dan Kementerian Industri dan Perdagangan Republik Sosialis Vietnam Tentang Kerja Sama di Bidang Pemanfaatan Gas Pada Wilayah Lintas Batas Landas Kontinen yang berisi tambahan pengaturan tentang tujuan MoU yang dicantumkan dalam substansi pasal, bidang kerja sama MoU, pengaturan keuangan, hak kekayaan intelektual, kelompok kerja bersama, kerahasiaan, amandemen, prinsip tidak-berprasangka, dan masa berlaku MoU. Untuk ketentuan yang tidak diatur dalam MoU ini akan menggunakan ketentuan yang ada di dalam Perjanjian Antara Perjanjian Antara Pemerintah Republik Indonesia dan Pemerintah Republik Sosialis Vietnam Tentang 
Penetapan Batas Landas Kontinen 2003.

Satu hal yang dapat disamakan dari perjanjian-perjanjian antara Pemerintah Republik Indonesia dengan negara lain ialah perjanjian-perjanjian tersebut secara langsung menegaskan posisi garis batas landas kontinennya beserta titiktitik koordinatnya melalui perundingan dan kesepakatan para pihak (negara). Untuk mekanisme penyelesaian sengketa atau perselisihan antara kedua negara, diselesaikan secara damai melalui musyawarah dan perundingan. Terlihat negara para peserta perjanjian termasuk Indonesia memang menghindari mekanisme penyelesaian sengketa melalui badan-badan penyelesaian sengketa internasional.

Indonesia sebagai negara yang telah meratifikasi UNCLOS 1982 yang sudah diundangkan di Indonesia sejak tahun 1985 melalui UU No. 17 Tahun 1985 telah mengambil langkah-langkah untuk menyesuaikan peraturan perundangundangannya mengenai hukum laut dengan rezim hukum laut dalam UNCLOS 1982, yakni UU No. 4 Prp. Tahun 1960 kini dinyatakan sudah tidak berlaku lagi karena sudah diganti dengan UU No. 6 Tahun 1996 (LNRI Nomor 73 Tahun 1996). ${ }^{20}$ Ketentuan lain mengenai hukum laut yang mendesak untuk disesuaikan dengan rezim hukum laut dalam UNCLOS 1982 ialah peraturan perundangundangan yang mengatur tentang landas kontinen. Berdasarkan praktek-praktek perjanjian yang telah diurai sebelumnya, baik yang dibuat sebelum maupun sesudah terbitnya UU No. 17 Tahun 1985 banyak menggunakan ketentuan yang mengadopsi rezim hukum laut dalam UNCLOS 1982 sebagai sumber hukum laut paling relevan dewasa ini. Hal tersebut dapat diperkuat dengan kesamaan sumber hukum laut internasional antara Indonesia dan negara tetangga (khususnya negara-negara yang telah mempunyai perjanjian tentang landas kontinen dengan Indonesia) karena negara-negara tetangga Indonesia juga telah meratifikasi UNCLOS 1982, dengan disesuaikannya peraturan perundang-undangan Indonesia mengenai landas kontinen, selaian akan relevan dengan rezim hukum laut saat ini, juga akan mempertegas dasar hukum Indonesia untuk urusan mengenai landas

\footnotetext{
${ }^{20}$ I Wayan Parthiana, Landas Kontinen Dalam Hukum Laut Internasional (Mandar Maju 2015).[109].
} 
kontinen dengan negara tetangga (khususnya untuk menyusun perjanjian) karena sekali lagi Indonesia dan negara-negara tetangga sudah berpegangan pada prinsipprinsip dan kaidah-kaidah rezim hukum laut yang sama.

\section{Kesimpulan}

Berdasarkan hasil kajian dan analisa pengaturan tentang Landas Kontinen di dalam UU No. 1 Tahun 1973 dengan UNCLOS 1982, terdapat perbedaan antara Ketentuan-ketentuan dalam rezim hukum laut UU No. 1 Tahun 1973 dan ketentuanketentuan dalam rezim hukum laut UNCLOS 1982, beberapa ketentuan telah di amandemen di dalam UNCLOS 1982, khususnya ketentuan mengenai pembangunan instalasi, Extended Continental Shelf, dan kewajiban yang berhubungan dengan kegiatan eksplorasi dan eksploitasi, serta pentingnya peran undang-undang nasional yang mengatur tentang ketentuan pidana di landas kontinennya. Hal ini mengisyaratkan bahwa UU No. 1 Tahun 1973 yang teknis penyusunannya masih mengacu kepada Convention on the Continental Shelf 1958 sudah tidak relevan dengan rezim hukum laut dalam UNCLOS 1982, namun UU No. 1 Tahun 1973 dan UNCLOS 1982 melalui UU No. 17 Tahun 1985 sama-sama berlaku di Indonesia hingga saat ini.

Dalam keberlakuan perjanjian-perjanjian terdapat kesamaan dalam bentuk dan pola substansinya, mulai dari penetapan kawasan yang ditetapkan sebagai garis batas landas kontinen yang disertai dengan titik-titik koordinatnya, dilanjutkan dengan pengaturan tentang sumber daya alam lintas batas, pengaturan sengketa, dan pengaturan pengesahan. Indonesia sebagai negara yang telah meratifikasi UNCLOS 1982 telah mengambil langkah-langkah untuk menyesuaikan peraturan perundang-undangannya mengenai hukum laut dengan membuat UU No. 6 Tahun 1996. Ketentuan lain mengenai hukum laut yang mendesak untuk disesuaikan dengan rezim hukum laut UNCLOS 1982 ialah peraturan perundang-undangan yang mengatur tentang landas kontinen. Berdasarkan praktek perjanjian-perjanjian, baik yang dibuat sebelum maupun sesudah terbitnya UU No. 17 Tahun 1985 banyak menggunakan ketentuan yang mengadopsi rezim hukum laut dalam UNCLOS 1982. 


\section{Daftar Bacaan}

\section{Buku}

R.R. Churcill dan A.V. Lowe, The Law Of The Sea Third Edition, Jurist Publishing (Manchester University Press 1999).

Mochtar Kusumaatmadja, Hukum Laut Internasional (Penerbit Binaputra 1998).

Boer Mauna, Hukum Internasional Pengertian Peranan Dan Fungsi Dalam Era Dinamika Global (Penerbit Alumni 2001).

I Wayan Parthiana, Landas Kontinen Dalam Hukum Laut Internasional (Mandar Maju 2015).

Peter Mahmud Marzuki, Penelitian Hukum (Kencana Prena Media Group 2008).

Dina Sunyowati dan Enny Narwati, Buku Ajar Hukum Laut (Pusat Penerbitan dan Percetakan Unair dengan LP3 Unair 2013).

\section{Jurnal}

Ratih D. Starina dan T. Fayakun Alif, “Analisa Revisi UU no 1 tahun 1973 tentang Landas Kontinen Indone sia yang mengacu pada UNCLOS 1958 dengan menggunakan UNCLOS 1982", (2003) Pusat Pemetaan Dasar Kelautan dan Kedirgantaraan BAKOSURTAN AL.

\section{Laman}

Suparman A. Diraputra, 'Laporan Akhir Tim Analisis Dan Evaluasi Peraturan Perundang-Undangan Tentang Landas Kontinen' <www.bbphn.go.id> diakses pada tanggal 17 Februari 2019.

\section{Perundang-undangan}

Undang-Undang Nomor 1 Tahun 1973 Tentang Landas Kontinen Indonesia (Lembaran Negara Republik Indonesia Tahun 1973 Nomor 1, Tambahan Lembaran Negara Republik Indonesia Nomor 2994).

Undang-Undang Nomor 17 Tahun 1985 Tentang Pengesahan United Nations Convention on the Law Of The Sea 1982 (Lembaran Negara Republik Indonesia Tahun 1985 Nomor 76, Tambahan Lembaran Negara Republik Indonesia Tahun 1985 Nomor 3319).

Undang-Undang Nomor 6 Tahun 1996 Tentang Perairan Indonesia (Lembaran Negara Republik Indonesia Tahun 1996 Nomor 73, Tambahan Lembaran 
Negara Republik Indonesia Nomor 3647).

Undang-Undang Nomor 22 Tahun 2001 Tentang Minyak dan Gas Bumi (Lembaran Negara Republik Indonesia Tahun 2001 Nomor 136, Tambahan Lembaran Negara Republik Indonesia Nomor 4152).

\section{Peraturan Pemerintah}

Peraturan Pemerintah Pengganti Undang-Undang Nomor 4 Tahun 1960 Tentang Perairan Indonesia (Lembaran Negara Republik Indonesia Tahun 1960 Nomor 22, Tambahan Lembaran Negara Republik Indonesia Nomor 1942).

Peraturan Pemerintah Nomor 38 Tahun 2002 Tentang Daftar Koordinat Geografis Titik-Titik Garis Pangkal Kepulauan Indonesia (Lembaran Negara Republik Indonesia Tahun 2002 Nomor 72, Tambahan Lembaran Negara Republik Indonesia Nomor 4211).

\section{Konvensi Internasional}

United Nations Convention on the Continental Shelf 1958.

United Nations Convention on the Law Of the Sea 1982.

\section{Perjanjian Internasional}

Perjanjian Antara Pemerintah Republik Indonesia dan Pemerintah Republik India Tentang Penetapan Garis Batas Landas Kontinen Antara Kedua Negara 1974.

Perjanjian Antara Pemerintah Republik Indonesia, Pemerintah Republik India dan Pemerintah Kerajaan Thailand Tentang Penetapan Titik Pertemuan Tiga Garis Batas dan Penetapan Garis Batas Ketiga Negara di Laut Andaman 1978.

Perjanjian Antara Pemerintah Republik Indonesia dan Pemerintah Republik Sosialis Vietnam Tentang Penetapan Batas Landas Kontinen 2003.

Memorandum of Understanding Antara Kementerian Energi dan Sumber Daya Mineral Republik Indonesia dan Kementerian Industri dan Perdagangan Republik Sosialis Vietnam Tentang Kerja Sama di Bidang Pemanfaatan Gas Pada Wilayah Lintas Batas Landas Kontinen. 